\title{
SHANK3 haploinsufficiency: a "common" but underdiagnosed highly penetrant monogenic cause of autism spectrum disorders
}

\author{
Catalina Betancur ${ }^{1,2,3^{*}}$ and Joseph D Buxbaum ${ }^{4}$
}

\begin{abstract}
Autism spectrum disorders (ASD) are etiologically heterogeneous, with hundreds of rare, highly penetrant mutations and genomic imbalances involved, each contributing to a very small fraction of cases. In this issue of Molecular Autism, Soorya and colleagues evaluated 32 patients with Phelan-McDermid syndrome, caused by either deletion of 22q13.33 or SHANK3 mutations, using gold-standard diagnostic assessments and showed that $84 \%$ met criteria for ASD, including 75\% meeting criteria for autism. This study and prior studies demonstrate that this syndrome appears to be one of the more penetrant causes of ASD. In this companion review, we show that in samples ascertained for ASD, SHANK3 haploinsufficiency is one of the more prevalent monogenic causes of ASD, explaining at least $0.5 \%$ of cases. We note that SHANK3 haploinsufficiency remains underdiagnosed in ASD and developmental delay, although with the increasingly widespread use of chromosomal microarray analysis and targeted sequencing of SHANK3, the number of cases is bound to rise.
\end{abstract}

Autism spectrum disorders (ASD) are highly genetic disorders, and current estimates indicate that there could be over 1,000 genes that contribute to ASD risk [1]. Very few genes are therefore likely to contribute to more than $1 \%$ of ASD, and mutations of FMR1 (the gene disrupted in Fragile $\mathrm{X}$ syndrome) and $M E C P 2$ (the gene disrupted in Rett syndrome), considered among the most common causes of ASD, explain $2 \%$ and $0.5 \%$ of ASD, respectively. Here we show that loss of a functional copy of SHANK3 is among the more prevalent rare causes of ASD.

SHANK3 codes for a scaffolding protein that lies at the core of the postsynaptic density in glutamatergic synapses. 22q13.3 deletions and mutations that lead to a loss of a functional copy of SHANK3 cause Phelan-McDermid syndrome, characterized by moderate to profound intellectual disability, severely delayed or absent speech, hypotonia, and ASD or ASD traits [2,3]. Dysmorphic features are usually mild and include dysplastic nails, large or prominent ears, long eyelashes, wide nasal bridge, bulbous nose and sacral dimple. Decreased perspiration, mouthing or chewing non-food items, and decreased perception of pain

\footnotetext{
* Correspondence: Catalina.Betancur@inserm.fr

'INSERM U952, Paris, France

${ }^{2}$ CNRS UMR 7224, Paris, France

Full list of author information is available at the end of the article
}

are frequently noted. Other features include seizures, brain, renal and cardiac malformations, motor deficits, gastroesophageal reflux, lymphedema, and immune defects. Because of its nonspecific clinical presentation, the diagnosis requires molecular genetic testing to identify SHANK3 deletions (the preferred method being chromosome microarray analysis) or mutations.

In this issue, Soorya and colleagues evaluated ASD in a sample of 32 patients with SHANK3 haploinsufficiency using standard diagnostic tests - the Autism Diagnostic Interview-Revised and the Autism Diagnostic Observation Schedule - and showed that $84 \%$ (27/32) met criteria for ASD, including 75\% (24/32) meeting criteria for autism. These findings indicate that Phelan-McDermid syndrome is one of the more highly penetrant causes of autism [4].

We can get a reasonably accurate estimate of the frequency of SHANK3 deletions and mutations in ASD through the review of recent studies in ASD that made use of either chromosome microarray or targeted resequencing of SHANK3. A survey of all relevant studies, including negative studies, indicates that at least $0.5 \%$ of subjects with ASD have haploinsufficiency at the SHANK3 locus. Table 1 shows 14 genome-wide microrray studies in ASD that would reliably detect larger dosage imbalance

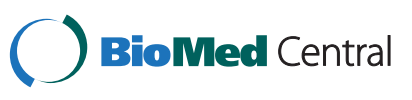


Table 1 22q13.3 deletions involving SHANK3 identified through microarray analyses in autism spectrum disorder samples

\begin{tabular}{lll}
\hline Study & Subjects & $\begin{array}{l}\text { 22q13.3 } \\
\text { deletions }\end{array}$ \\
\hline Sebat et al. [5] & 165 & 1 de novo \\
Moessner et al. [6] & 400 & 2 de novo ${ }^{a}$ \\
Weiss et al. [7] & $299^{\mathrm{b}}$ & 0 \\
van der Zwaag et al. [8] & 105 & 0 \\
Guilmatre et al. [9] & 260 & 2 de novo \\
Qiao et al. [10] & 100 & 0 \\
Schaefer et al. [11] & 68 & 0 \\
Pinto et al. [12] + Autism Genome Project & 2,446 & 3 de novo \\
(manuscript in preparation) & & \\
Shen et al. [13] & 848 & 0 \\
Rosenfeld et al. [14] & 1,461 & 4 (2 de novo, \\
Bremer et al. [15] & & 2 unknown) \\
Sanders et al. [16] & 223 & 1 de novo \\
Wisniowiecka-Kowalnik et al. [17] & 1,124 & 0 \\
Girirajan et al. [18] & 145 & 0 \\
Total & 243 & 0 \\
\hline
\end{tabular}

a Family 3524, with two affected siblings with an apparent de novo SHANK3 deletion, was part of another cohort and was thus not included here. In addition, this family's deletion was previously reported in Sebat et al. [5] b 299 patients from deCODE (Iceland); subjects from AGRE and Boston Children's Hospital overlap other studies and were not included here. c One family (2072) was already reported in Sebat et al. [5] (89-3524-100) and Moessner et al. [6] (3524), and was not included here.

at SHANK3. These studies included 7,887 affected individuals, and collectively identified 13 deletions $(0.16 \%)$. This frequency is likely underestimated because, in many of these studies, efforts were made at the recruiting sites to exclude cases with severe intellectual disability or syndromic autism (that is, those with dysmorphic features or other congenital anomalies). In addition, many of the patient samples had been prescreened for cytogenetic abnormalities and microdeletion/microduplication syndromes. Furthermore, although we tried to exclude studies that had clearly overlapping samples, there are probable sample overlaps among the remaining studies (overlapping

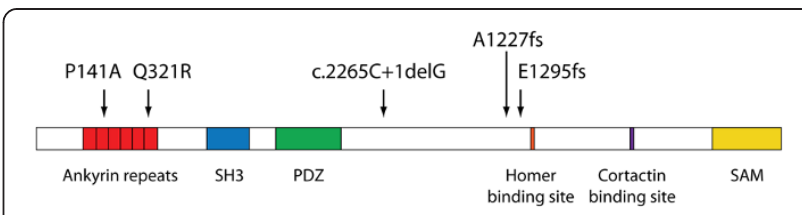

Figure 1 De novo SHANK3 mutations identified through large-scale surveys in autism spectrum disorders. See Table 2 for references.

ASD cases without a deletion would lead to apparently decreased rates of the deletion). Moreover, because PhelanMcDermid syndrome is a mostly sporadic disorder (the deletion is de novo in $80 \%$ of cases, while in $20 \%$ it results from familial balanced translocations or other chromosome rearrangements), screening ASD samples with an overrepresentation of multiplex families will necessarily result in a lower yield. Finally, it should be noted that most of the microarray analyses reviewed here would have missed small deletions involving only SHANK3.

There have been five studies in ASD that have examined SHANK3 for mutations, using targeted resequencing (Table 2 and Figure 1). These studies identified five de novo deleterious mutations in 1,614 subjects with ASD (0.31\%). The combined rate of deletions and mutations in ASD is therefore 0.5\%, making haploinsufficiency at the SHANK3 locus one of the more common monogenic causes of ASD. Studies in intellectual disability and developmental delay confirm this rate of SHANK3 haploinsufficiency in these disorders as well [19-21].

In conclusion, recent studies of patients with ASD indicate that SHANK3 haploinsufficiency is found in approximately $0.5 \%$ of individuals with ASD. In addition, Soorya and colleagues and prior publications indicate that a very high proportion of individuals with SHANK3 haploinsufficiency have ASD.

Chromosome microarray analysis is still not routinely carried out for individuals with unexplained developmental delay or ASD, in spite of recommendations from several expert societies. In addition, SHANK3 is one of the most GC-rich genes in the genome, and targeted resequencing requires considerable optimization to reliably sequence this gene. As a result, few clinical laboratories

Table 2 De novo SHANK3 mutations identified through large-scale screening of autism spectrum disorder samples

\begin{tabular}{llllll}
\hline Study & Subjects & Mutations & Nucleotide $^{\mathbf{a}}$ & Protein $^{\mathbf{b}}$ & Exon/intron \\
\hline Durand et al. [2] & 227 & 1 & g.51159940-51159941insG & p.A1227fs & exon 21 \\
Moessner et al. [6] & 400 & 1 & g.51121844A>G & p.Q321R & exon 8 \\
Gauthier et al. [22] & 427 & 1 & g.51153476delG & (splice site deletion) & intron 19 \\
Schaaf et al. [23] & 339 & 0 & & p.P141A & exon 4 \\
Boccuto et al. [24] & 221 & 2 & g.51117094C>G & p.E1295fs & exon 21 \\
Total & & & g.51160144delG & \\
\hline a Genomic locations are based on GRCh37 (hg 19). ${ }^{\mathbf{b}}$ SHANK3 reference sequence NM_033517.1 (mRNA) and NP_277052.1 (protein).
\end{tabular}

${ }^{\mathrm{a}}$ Genomic locations are based on GRCh37 (hg 19). ${ }^{\mathrm{b}}$ SHANK3 reference sequence NM_033517.1 (mRNA) and NP_277052.1 (protein). 
screen SHANK3 routinely. Furthermore, whole exome sequencing does a very poor job of adequately covering SHANK3 because of the GC content. Thus, both clinical and research studies will need to continue to use chromosome microarray analyses and Sanger methods to query this important gene, until better whole-exome or wholegenome sequencing protocols are developed. For all these reasons, Phelan-McDermid syndrome remains undiagnosed in many individuals, denying them and their families any benefits that derive from an etiological diagnosis. As Phelan-McDermid syndrome continues to be studied we will understand more about this disorder, including natural history and therapies that are most beneficial for this group of individuals.

\section{Abbreviations}

ASD: Autism spectrum disorders.

\section{Competing interests}

CB and JDB are co-authors of the paper by Soorya and colleagues.

\section{Acknowledgements}

We thank the families affected by Phelan-McDermid syndrome for their participation in our respective research studies and for their ongoing support.

\section{Author details}

${ }^{1}$ INSERM U952, Paris, France. ${ }^{2}$ CNRS UMR 7224, Paris, France. ${ }^{3}$ Université Pierre et Marie Curie, Paris, France. ${ }^{4}$ Seaver Autism Center for Research and Treatment, Departments of Psychiatry, Neuroscience, and Genetics and Genomic Sciences, Friedman Brain Institute, and Mindich Child Health and Development Institute, Icahn School of Medicine at Mount Sinai, New York, NY 10029, USA.

Received: 24 May 2013 Accepted: 29 May 2013

Published: 11 June 2013

\section{References}

1. Betancur C: Etiological heterogeneity in autism spectrum disorders: more than 100 genetic and genomic disorders and still counting. Brain Res 2011, 1380:42-77.

2. Durand CM, Betancur C, Boeckers TM, Bockmann J, Chaste P, Fauchereau F, Nygren G, Rastam M, Gillberg IC, Anckarsater H, et al: Mutations in the gene encoding the synaptic scaffolding protein SHANK3 are associated with autism spectrum disorders. Nat Genet 2007, 39(1):25-27.

3. Phelan K, McDermid HE: The 22q13.3 deletion syndrome (Phelan-McDermid syndrome). Mol Syndromol 2012, 2(3-5):186-201.

4. Betancur $C$, Coleman M: Etiological heterogeneity in autism spectrum disorders: role of rare variants. In The Neuroscience of Autism Spectrum Disorders. Edited by Buxbaum JD, Hof PR. Oxford: Academic; 2013:113-144.

5. Sebat J, Lakshmi B, Malhotra D, Troge J, Lese-Martin C, Walsh T, Yamrom B, Yoon S, Krasnitz A, Kendall J, et al: Strong association of de novo copy number mutations with autism. Science 2007, 316(5823):445-449.

6. Moessner $R$, Marshall CR, Sutcliffe JS, Skaug J, Pinto D, Vincent J, Zwaigenbaum L, Fernandez B, Roberts W, Szatmari P, et al: Contribution of SHANK3 mutations to autism spectrum disorder. Am J Hum Genet 2007, 81(6):1289-1297.

7. Weiss LA, Shen Y, Korn JM, Arking DE, Miller DT, Fossdal R, Saemundsen E, Stefansson H, Ferreira MA, Green T, et al: Association between microdeletion and microduplication at 16p11.2 and autism. N Engl J Med 2008, 358(7):667-675.

8. van der Zwaag B, Franke L, Poot M, Hochstenbach R, Spierenburg HA, Vorstman JA, van Daalen E, de Jonge MV, Verbeek NE, Brilstra EH, et al: Gene-network analysis identifies susceptibility genes related to glycobiology in autism. PLoS One 2009, 4(5):e5324

9. Guilmatre A, Dubourg C, Mosca AL, Legallic S, Goldenberg A, Drouin-Garraud V, Layet V, Rosier A, Briault S, Bonnet-Brilhault F, et al: Recurrent rearrangements in synaptic and neurodevelopmental genes and shared biologic pathways in schizophrenia, autism, and mental retardation. Arch Gen Psychiatry 2009, 66(9):947-956

10. Qiao Y, Riendeau N, Koochek M, Liu X, Harvard C, Hildebrand MJ, Holden JJ, Rajcan-Separovic E, Lewis ME: Phenomic determinants of genomic variation in autism spectrum disorders. J Med Genet 2009, 46(10):680-688.

11. Schaefer GB, Starr L, Pickering D, Skar G, Dehaai K, Sanger WG: Array comparative genomic hybridization findings in a cohort referred for an autism evaluation. J Child Neurol 2010, 25(12):1498-1503.

12. Pinto D, Pagnamenta AT, Klei L, Anney R, Merico D, Regan R, Conroy J, Magalhaes TR, Correia C, Abrahams BS, et al: Functional impact of global rare copy number variation in autism spectrum disorders. Nature 2010, 466(7304):368-372.

13. Shen Y, Dies KA, Holm IA, Bridgemohan C, Sobeih MM, Caronna EB, Miller KJ, Frazier JA, Silverstein I, Picker J, et al: Clinical genetic testing for patients with autism spectrum disorders. Pediatrics 2010, 125(4):e727-e735.

14. Rosenfeld JA, Ballif BC, Torchia BS, Sahoo T, Ravnan JB, Schultz R, Lamb A, Bejjani BA, Shaffer LG: Copy number variations associated with autism spectrum disorders contribute to a spectrum of neurodevelopmental disorders. Genet Med 2010, 12:694-702.

15. Bremer A, Giacobini M, Eriksson M, Gustavsson P, Nordin V, Fernell E, Gillberg C, Nordgren A, Uppstromer A, Anderlid BM, et al: Copy number variation characteristics in subpopulations of patients with autism spectrum disorders. Am J Med Genet B Neuropsychiatr Genet 2011, 156(2):115-124.

16. Sanders SJ, Ercan-Sencicek AG, Hus V, Luo R, Murtha MT, Moreno-De-Luca D, Chu SH, Moreau MP, Gupta AR, Thomson SA, et al: Multiple recurrent de novo CNVs, including duplications of the $7 q 11.23$ Williams syndrome region, are strongly associated with autism. Neuron 2011, 70(5):863-885.

17. Wisniowiecka-Kowalnik B, Kastory-Bronowska M, Bartnik M, Derwinska K, Dymczak-Domini W, Szumbarska D, Ziemka E, Szczaluba K, Sykulski M, Gambin T, et al: Application of custom-designed oligonucleotide array $\mathrm{CGH}$ in 145 patients with autistic spectrum disorders. Eur J Hum Genet 2013, 21(6):620-625.

18. Girirajan S, Johnson RL, Tassone F, Balciuniene J, Katiyar N, Fox K, Baker C, Srikanth A, Yeoh KH, Khoo SJ, et al: Global increases in both common and rare copy number load associated with autism. Hum Mol Genet 2013, advance online publication, doi:10.1093/hmg/ddt136.

19. Hamdan FF, Gauthier J, Araki Y, Lin DT, Yoshizawa Y, Higashi K, Park AR, Spiegelman D, Dobrzeniecka S, Piton A, et al: Excess of de novo deleterious mutations in genes associated with glutamatergic systems in nonsyndromic intellectual disability. Am J Hum Genet 2011, 88(3):306-316.

20. Cooper GM, Coe BP, Girirajan S, Rosenfeld JA, Vu TH, Baker C, Williams C, Stalker H, Hamid R, Hannig V, et al: A copy number variation morbidity map of developmental delay. Nat Genet 2011, 43(9):838-846.

21. Gong $X$, Jiang YW, Zhang $X$, An Y, Zhang J, Wu Y, Wang J, Sun Y, Liu Y, Gao $X$, et al: High proportion of $22 q 13$ deletions and SHANK3 mutations in Chinese patients with intellectual disability. PLoS One 2012, 7(4):e34739.

22. Gauthier J, Spiegelman D, Piton A, Lafreniere RG, Laurent S, St-Onge J, Lapointe L, Hamdan FF, Cossette P, Mottron L, et al: Novel de novo SHANK3 mutation in autistic patients. Am J Med Genet B Neuropsychiatr Genet 2009, 150B(3):421-424.

23. Schaaf CP, Sabo A, Sakai Y, Crosby J, Muzny D, Hawes A, Lewis L, Akbar H,

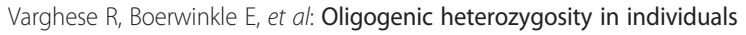
with high-functioning autism spectrum disorders. Hum Mol Genet 2011, 20(17):3366-3375.

24. Boccuto L, Lauri M, Sarasua SM, Skinner CD, Buccella D, Dwivedi A, Orteschi D, Collins JS, Zollino M, Visconti P, et al: Prevalence of SHANK3 variants in patients with different subtypes of autism spectrum disorders. Eur J Hum Genet 2013, 21(3):310-316.

doi:10.1186/2040-2392-4-17

Cite this article as: Betancur and Buxbaum: SHANK3 haploinsufficiency: a "common" but underdiagnosed highly penetrant monogenic cause of autism spectrum disorders. Molecular Autism 2013 4:17. 